\title{
Validated age and growth estimates of two clam species in a saltwater lake on the Suez Canal in Egypt
}

\author{
Raouf Kilada \\ Department of Marine Sciences, Faculty of Science, Suez Canal \\ University, Egypt. \\ E-mail: rkilada@unb.ca
}

\begin{abstract}
$\mathrm{T}$ his is the first time to document the validated age and growth estimates for two clam species; Ruditapes decussatus, and Gafrarium pectinatum in Lake Timsah, which is a salt water lake on the Suez Canal in Egypt. Age validation for the two species was done to confirm the annual deposition of each growth increments on the shell surface and was conducted using the edge analysis method. Age validation of these two species showed that the period of the major growth was summer, while the slower growth was documented in winter. The age of the two species was determined by counting the growth increments on the shell surface. Maximum age for $R$. decussatus (4 y) and G. pectinatum (3 y) were recorded in a $37.2 \mathrm{~mm}$ and $42.1 \mathrm{~mm}$ in the two species, respectively. Also, length frequency analysis using FiSAT was used to confirm the number of year classes (age) in the two species. The von Bertalanffy Growth Parameters; $\mathrm{L}_{\infty}, \mathrm{k}$ and $\mathrm{t}_{\mathrm{o}}$, were $40.4 \mathrm{~mm}, 0.268$ and $-1.11 \mathrm{y}$ for $R$. decussatus and $36.3 \mathrm{~mm}, 0.81$ and $0.05 \mathrm{y}$ for G. pectinatum. Besides age, the morphometric characters of the two species were discussed. The results of this study will help in better fisheries and ecosystem management.
\end{abstract}

Keywords: age determination, validation, Lake Timash, Ruditapes decussatus, Gafrarium pectinatum.

\section{INTRODUCTION}

Lake Timsah is one of three lakes that are connected to the Suez Canal in Egypt. The lake bottom is mainly muddy or sandy and is the habitat of a wide range of ecological and economical important taxa such as the clams of family Veneridae (Gabr \& Gab-Alla, 2008). Among these clams are Ruditapes decussatus (Linnaeus 1758) and Gafrarium pectinatum (Linnaeus 1758) that are been collected on a commercial scale. Few studies were published to address the commercial importance of clam species in the area. For example, Yassin et al. (2009) documented the fisheries statistics in the region and mentioned that $R$. decussatus and G. pectinatum make up to $25 \%$ of the clam fisheries in Lake Timash. The authors also showed that there was an increase in the total clam catch from $499 \mathrm{t}$ in 1999 to $2088 \mathrm{t}$ in 2006 and then declined in 2008 to $1793 \mathrm{t}$. There are no available literature about the age and growth of the carpet shell 
clam, Ruditapes decussatus in Lake Timsah. Nevertheless, the population dynamics of the same species was investigated in other locations, for example, in UK (Urrutia et al., 1999), Greece (Chryssanthakopoulou \& Kaspiris, 2005) and Turkey (Serdar et al., 2007). On the other hand, few studies are available for Gafrarium pectinatum in Egyptian waters. Gab-Alla et al. (2007) for example, studied its reproductive biology besides analyzing its length frequency over one year in northern Red Sea.

Knowledge of growth parameters is essential for understanding the biology and productivity of bivalves. Studying vital rates (namely growth) is necessary for modeling population dynamics, which, in turn, is crucial to support exploitation and management (Peharda et al., 2007) and to propose effective measures for the protection of the species (Katsanevakis, 2007). Growth rates also indicate how much time is required to reach a certain marketable size (Urban, 2000), and the relationship between size and age is essential to implement appropriate management strategies (Keller et al., 2002). Several methods are used to estimate age and growth of bivalves, but there are practical problems with most of them. Size-frequency distribution analysis is a subjective method, inappropriate for species with a relatively long annual recruitment period and/or highly variable individual growth rates within age groups (Cerrato, 1980). Mark and recapture experiments demand a lot of time to gather data and should only be carried out in areas where fishing activities are prevented (Gaspar, et al., 2004). Analyses of oxygen and carbon isotopic composition are also used for determining the age of bivalves, although the determination of equilibrium or disequilibrium conditions between carbonate and seawater is often difficult, chiefly when large changes in both temperature and seawater isotopic composition take place throughout time (Keller et al., 2002). Besides these methods, counting growth increments on the shell surface or on thin sections of whole valve or of the chondrophore region have proven to be among the most efficient techniques to determine the age of various bivalve species (Ropes and Jearld, 1987).

Meanwhile, age validation is essential to confirm that the increments used in counting are deposited annually and reflect the absolute age of the species (Campana, 2001). Methods that are used in the age validation include the release of known age and marked individual where the animals can be marked either externally (Quinn et al., 1991), or immersion mass-marked using temperature fluctuations (Volk et al., 1999) or chemicals (Campana, 1999). A different technique that is used successfully to validate the annual deposition of growth increments in aquatic animals is the bomb radiocarbon. This technique is recommended for long living species and was used with fish (Campana \& Jones, 1998) and with bivalves (Kilada et al., 2007a; Kilada et al., 2009). A third validation method is the otolith or shell marginal increment analysis (MIA) which is the most commonly used for fish (Carlson et al., 1999) and was applied successfully in bivalves (Kilada et al., 2007b). Moreover, the edge analysis is a 
different validation method which has similar propertied to MIA and is used to record the presence of the marginal increments as opaque or translucent zones (Labropoulou \& Papaconstantinou 2000). The absence of age and growth information initiated the importance of the present study which presents the first report of the validated age structure and growth of two clam species living in Timsah Lake. The clam age is determined by counting the growth increments on the shell surface of the two species in addition to the use of length frequency analysis. Age validation is conducted to confirm the annual deposition of each increment and is done using the edge analysis. Besides age and growth, the study will investigate the morphometric characters of the two clam species in Lake Timash. These characters should indicate the growth trend in the shell relatively to the flesh of each species.

\section{MATERIALS AND METHODS}

The study was conducted in the salt-water Lake Timsah which is located on the Suez Canal at $30^{\circ} 34^{\prime} \mathrm{N}$ and $32^{\circ} 18^{\prime} \mathrm{E}$. The average water depth in the lake is about $6 \mathrm{~m}$ although some areas are $16 \mathrm{~m}$ deep. The salinity in the lake varies between $36 \%$ and $44 \%$ and temperature varies between $15^{\circ} \mathrm{C}$ in December and $28^{\circ} \mathrm{C}$ in August.

\section{Morphometric Measurements:}

Sampling of Ruditapes decussatus and Gafrarium pectinatum were carried out at monthly intervals between November 2008 and October 2009. In each month, a sample of 50 -60 individuals of each species was randomly collected by hand from depths ranging less than $1 \mathrm{~m}$. Total number for $R$. decussatus and $G$. pectinatum was 626 and 699, respectively. The shell length (SL, maximum distance along the anterior-posterior axis), width ( $\mathrm{SW}$, maximum distance along the 2 valves-lateral axes) and height ( $\mathrm{SH}$, maximum distance along the dorsal-ventral axis) were measured to the nearest $0.1 \mathrm{~mm}$. The total weight of each clam was determined and then the shell was separated from the soft tissues, which were weighed after being drained from excess water. The dry weight of soft tissue was recorded after keeping the tissue in an oven at $100{ }^{\circ} \mathrm{C}$ for $48 \mathrm{~h}$. The mean and range of all measurements are recorded in Table 1.

The length-height and width relationships were described by a linear regression:

$$
\boldsymbol{Y}=\boldsymbol{a}+\boldsymbol{b} \boldsymbol{X}
$$

where $\mathrm{Y}$ is the clam height $(\mathrm{mm})$ and $\mathrm{X}$ is the length $(\mathrm{mm})$. Length-weight relationships were calculated using the equation:

$$
\boldsymbol{Y}=\boldsymbol{a} * \boldsymbol{X}^{\boldsymbol{b}}
$$

where $Y$ is a weight variable (total dry tissue weight, $\mathrm{g}$ ) and $X$ is the shell length $(\mathrm{mm}) ; a$ and $b$ are model parameters. In order to assess if the $b$ value obtained in the linear and non-linear regressions was significantly different from the isometric value of $b=1$ and 3 , respectively, a t-test $\left(\mathrm{H}_{0}: \mathrm{b}=1\right)$ with a confidence level of $95 \%(a=0.05)$ was applied. Calculated $b$ values of 1 (length-height) or 3 (length-weight) were defined as being in the isometric range, while $b<1$ (3) 
was defined as negative allometry and $b>1$ (3) as positive allometry. The relationships between the wet and dry flesh weight was done to examine the flesh water content.

\section{Age determination}

The age was determined in 90 and 94 individuals of $R$. decussatus and G. pectinatum, respectively by counting the growth rings observed on the shell surface of each individual after cleaning. The increments were also investigated in a thin section of the chondrophore region. Thin section was prepared by sectioning the shell along the anterior-posterior axis with a low-speed Isomet saw mounted with two diamond blades, $2 \mathrm{~mm}$ apart. The thin section was mounted on a glass slide and ground down to $140 \mu \mathrm{m}$ thickness with a Buehler PETRO-THIN thin sectioning system. The section surface was hand ground with silicon carbide grinding powder of grit size 200 and then examined using an Olympus binocular microscope using reflected light at $40 \mathrm{x}$ magnification. The growth increments were counted in the chondrophore region.

The von Bertalanffy growth curves for all age-length data of the two species were fitted by non-linear regression using the statistical package SYSTAT (2009):

$$
\mathbf{L}_{\mathbf{t}}=\mathbf{L}_{\infty}\left(\mathbf{1}-\mathbf{e}^{\left(-\mathbf{k}\left(\mathbf{t}_{\circ} \mathrm{t}_{\circ}\right)\right.}\right)
$$

where $L_{t}$ is the length-at-age $t ; k$ is a growth coefficient; $L_{\infty}$ is the asymptotic length and $t_{o}$ is the theoretical age at 0 length.

To examine precision, number of growth increments on the shell surface of both species was made by two readers for each specimen independently. The bias graph displays the number of growth increments obtained by one reader against a second reader in reference to an equivalence line where the ager 1 has the same results of ager 2. Specifically, for all animals assigned a given age by ager 1, the mean age and $95 \%$ confidence intervals of the ages assigned by ager 2 are plotted against the ager 1 results (Campana et al., 1995; Campana, 2001; Kilada et al., 2007). Precision estimates were calculated by using the coefficient of variation (CV) as described by Chang (1982) and Morales-Nin and Panfili (2002):

$$
C V I=100 * \frac{\sqrt{\sum_{i=1}^{k} \frac{(x i j-\bar{x})^{2}}{R-1}}}{\bar{x} l}
$$

where $X_{i j}$ is the $i^{\text {th }}$ age estimate of the $j^{\text {th }}$ clam, $\overline{\mathbf{x}}$ is the mean age of the $j^{\text {th }}$ clam, and $R$ is the number of times each clam is aged. $\mathrm{CV}$ is averaged across clams to produce a mean. $\mathrm{CV}$ is more flexible and statistically more robust than other measures of precision, such as percent agreement or average percent error (Kimura \& Lyons, 1991).

Age Validation:

The validation procedure was used to confirm the annual deposition of single growth increment on the shell surface and to determine the time of 
deposition. Age validation for $R$. decussatus and $G$. pectinatum was done by applying the edge analysis which records the presence of the marginal increment as either an opaque or translucent zone (Gaspar et al., 1995; van der Walt \& Beckley, 1997; Labropoulou \& Papaconstantinou, 2000; Campana, 2001; Gasper et al., 2004). The edge analysis method investigates the change in relative frequency of each edge zone which is plotted across seasons where the cycle frequency should equal one year in true annuli. The marginal increment checked by Olympus SZX16 at x 10 magnification.

\section{Length-Frequency Analysis:}

Total number of clams used in the length-frequency was 626 and 699 individuals of $R$. decussatus and G. pectinatum, respectively. Length-frequency distributions were calculated per $1 \mathrm{~mm}$ size-classes and the modal length of the cohorts was identified applying the Bhattacharya method (1967) using the FISAT software package (Gayanilo et al., 2005).

\section{Morphometric Measurements:}

\section{RESULTS}

Morphometric relationships between several size parameters in the two clam species are presented in Tables 1 and 2 . The allometric coefficient $(b$, slope) of these relationships is related allometrically in all cases and reflects ontogenetic changes in the shell and flesh. The shell of $R$. decussatus and $G$. pectinatum tend to become proportionally higher and wider (positive allometric, $b>1, P>0.01$ ) possibly providing better anchorage in the mobile sediment for larger animals.

Table 1: Mean, range and Standard Error (SE) of morphometric measurements in the two species collected from Lake Timsah.

\begin{tabular}{|c|l|c|c|c|c|c|}
\hline Species & \multicolumn{1}{|c|}{ Variable } & n & Minimum & Maximum & Mean & $\begin{array}{c}\text { Standard } \\
\text { Error }\end{array}$ \\
\hline \multirow{4}{*}{ Ruditapes } & Shell Length (mm) & 627 & 16.40 & 38.00 & 26.16 & 0.15 \\
decussatus & Shell Width (mm) & 625 & 10.00 & 29.00 & 18.58 & 0.12 \\
& Shell Height (mm) & 625 & 7.30 & 17.50 & 11.12 & 0.07 \\
& Total Weight (g) & 625 & 0.61 & 9.56 & 3.04 & 0.05 \\
& Dry Flesh Weight (g) & 624 & 0.05 & 0.88 & 0.21 & 0.01 \\
\hline \multirow{5}{*}{ Gafrarium } & Shell Length (mm) & 519 & 19.20 & 52.40 & 29.39 & 0.211 \\
pectinatum & Shell Width (mm) & 519 & 14.70 & 40.20 & 21.90 & 0.15 \\
& Shell Height (mm) & 519 & 6.60 & 20.10 & 10.67 & 0.09 \\
& Total Weight (g) & 518 & 1.32 & 24.87 & 5.03 & 0.12 \\
& Dry Flesh Weight (g) & 515 & 0.03 & 1.40 & 0.24 & 0.01 \\
\hline
\end{tabular}


Table 2: Morphometric relationship parameters for $R$. decussatus and G. pectinatum from Lake Timsah. Values between parentheses are the upper and lower $95 \%$ confidence levels.

\begin{tabular}{|c|l|c|c|c|c|c|}
\hline \multicolumn{1}{|c|}{ Species } & \multicolumn{1}{|c|}{$\begin{array}{c}\text { Morphometric } \\
\text { Relationship }\end{array}$} & $\mathbf{n}$ & $\mathbf{r}^{2}$ & $\mathbf{a}$ & $\mathbf{b}$ & Allometry \\
\hline & SW - SL & 625 & 0.83 & $\begin{array}{c}4.53 \\
(3.75-5.30)\end{array}$ & $\begin{array}{c}1.16 \\
(1.12-1.20)\end{array}$ & Positive \\
\cline { 2 - 7 } & SH - SL & 623 & 0.86 & $\begin{array}{c}5.04 \\
(4.35-5.72)\end{array}$ & $\begin{array}{c}1.90 \\
(1.834-1.956)\end{array}$ & Positive \\
\cline { 2 - 7 } & TW - SL & 624 & 0.89 & $\begin{array}{c}0.0001 \\
(0.00-0.00)\end{array}$ & $\begin{array}{c}2.83 \\
(2.75-2.90)\end{array}$ & Isometric \\
\cline { 2 - 7 } & FDW - SL & 623 & 0.72 & $\begin{array}{c}0.0001 \\
(0.00009- \\
0.000011)\end{array}$ & $\begin{array}{c}3.13 \\
(2.98-3.28)\end{array}$ & Isometric \\
\cline { 2 - 7 } & FWW - FDW & 624 & 0.86 & $\begin{array}{c}-0.022 \\
(-0.031--\end{array}$ & $\begin{array}{c}0.20 \\
(0.19-0.20)\end{array}$ & Negative \\
\hline \multirow{5}{*}{ G. pectinatum } & SW - SL & 699 & 0.94 & $\begin{array}{c}-1.47 \\
(-2.08--0.87)\end{array}$ & $\begin{array}{c}1.42 \\
(1.39-1.443\end{array}$ & Positive \\
\cline { 2 - 7 } & TW - SL & 699 & 0.87 & $\begin{array}{c}5.64 \\
(4.90-6.38)\end{array}$ & $\begin{array}{c}2.25 \\
(2.19-2.32)\end{array}$ & Positive \\
\cline { 2 - 7 } & TW - SL & 697 & 0.90 & $\begin{array}{c}0.001 \\
(0.001-0.001)\end{array}$ & $\begin{array}{c}2.530 \\
(2.473-2.587)\end{array}$ & Negative \\
\cline { 2 - 7 } & FDW - SL & 694 & 0.68 & $\begin{array}{c}0.0001 \\
(0.00009- \\
0.000011)\end{array}$ & $\begin{array}{c}-0.04 \\
(2.57-2.83)\end{array}$ & Negative \\
\cline { 2 - 7 } & FWW - FDW & 515 & 0.94 & $\begin{array}{c}0.23 \\
(-0.05--0.03)\end{array}$ & Negative \\
\hline
\end{tabular}

\section{Age determination:}

Examination of shell sections showed distinct growth patterns within the shell of the two species and identified a wide light-colored band followed by a narrow dark-colored growth band (Fig. 1A). These bands were found to correspond to the wide opaque and the narrow light areas noticed on the external surface of the shells (Figs $1 \mathrm{~B}-\mathrm{C}$ ). The same number of increments was visible in the thin sections of the chondrophore region as well as on the shell surface of both species and therefore, the external shell was used for the age determination in all clams. In $R$. decussatus and G. pectinatum, the maximum number of increments was 4 and 3, respectively. The maximum age in the former was found in a 37.20 $\mathrm{mm}$ SL individual, while in $G$. pectinatum, the maximum age was recorded in $42.10 \mathrm{~mm}$ SL clam. The von Bertalanffy growth parameters (VBGP) of $R$. decussatus and $G$. pectinatum was estimated from the length-at-age relationship (Fig. 2; Table 3) and the mean length at each year class were estimated (Table 4). 
Table 3: Von Bertalanffy parameters calculated from the age-length relationship for $R$. decussatus and $G$. pectinatum. Values between parentheses are the upper and lower $95 \%$ confidence levels.

\begin{tabular}{|c|c|c|}
\hline & R. decussatus & G. pectinatum \\
\hline \multirow{2}{*}{$\mathbf{L}_{\infty}$} & 40.41 & 36.31 \\
& $(35.50-45.33)$ & $(32.94-39.67)$ \\
\hline \multirow{2}{*}{$\mathbf{K}$} & 0.268 & 0.81 \\
& $(0.20-0.33)$ & $(0.47-1.16)$ \\
\hline \multirow{2}{*}{$\mathbf{t}_{\mathbf{0}}$} & -1.106 & 0.053 \\
& $(-1.42--0.79)$ & $(0.03-0.06)$ \\
\hline
\end{tabular}
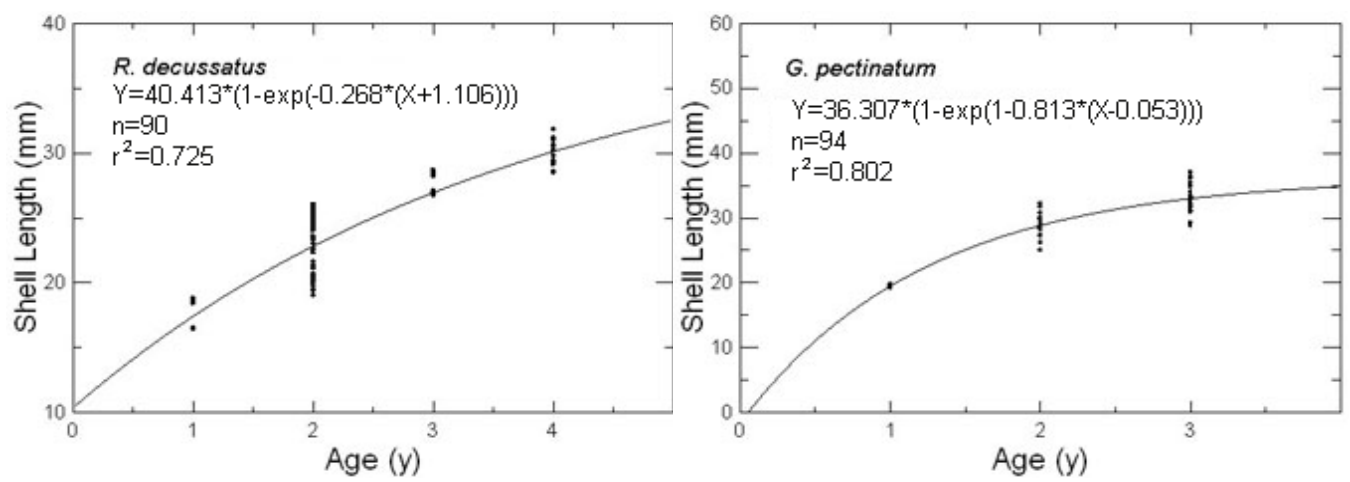

Fig. 2: Growth curve for R. decussatus and G. pectinatum collected from Lake Timsah.

The Bias plot comparing the results of the two readers indicated no bias in the ageing process (Fig. 3).
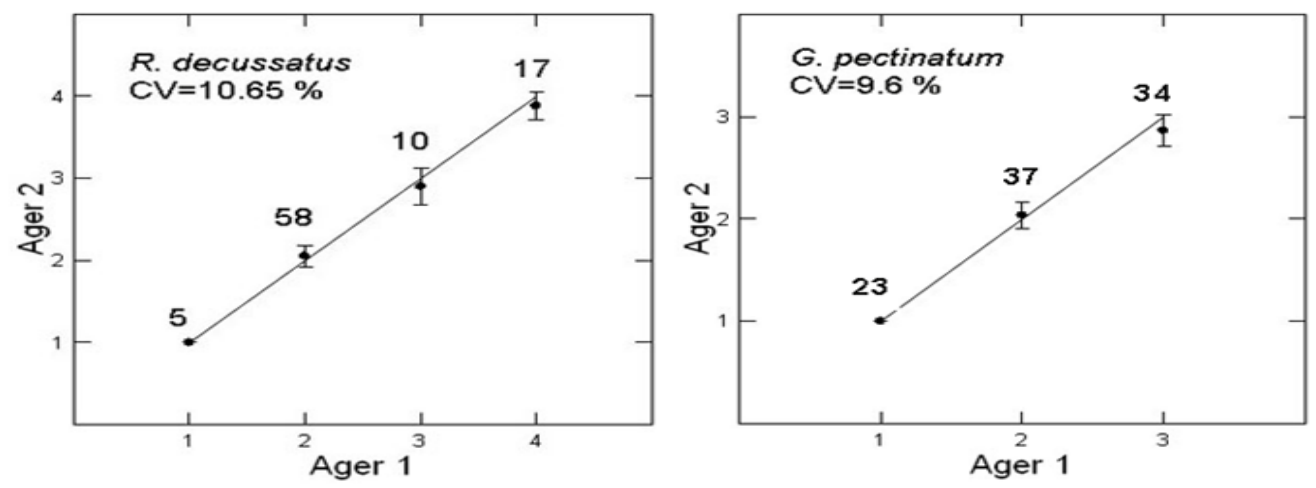

Fig. 3: Age bias graph for $R$. decussatus and G. pectinatum for age reader 1 and 2 aging the clam by counting the growth increments on the shell surface. Each error bar represents the 95 $\%$ confidence interval about the mean age assigned by ager 2 to all clams assigned a given age by ager 1 . The values indicate the number of clams aged at each age group and the solid line represents 1:1 equivalence.

$(\mathrm{Cv}=$ Coefficient of variation $)$. 
Also the mean coefficient of variation $(\mathrm{CV})$ that measures the precision was found to be $10.65 \%$ and $9.6 \%$ for $R$. decussatus and G. pectinatum, respectively. There is no absolute rule for an acceptable $\mathrm{CV}$ for ageing studies as precision is affected by longevity, the structure used for ageing and the difficulty in reading the growth increments. In fish, a CV of $5 \%$ is considered as limit for acceptable age readings for short lived species (Laine et al., 1991) although Campana, (2001) states that $\mathrm{CV}$ of $5 \%$ is common in fish. The result in the present study was thus considered precise and unbiased, and therefore the counts generated by one reader for the entire set of shells were used for the analysis.

\section{Length-Frequency Analysis:}

The analysis revealed that there are 4 and 3 modes in the length-frequency data for $R$. decussatus and G. pectinatum, respectively (Fig. 5). The mean length of each mode was calculated and was found to be comparable to mean of length at age that was calculated from the von Bertalanffy equation for each species (Table 4).

Table 4: Mean length (mm) at each year class for R. decussatus and G. pectinatum. The values are provided from von Bertalanffy equation and from the lengthfrequency analysis using FiSAT package.

\begin{tabular}{|l|c|c|c|c|c|c|c|c|}
\hline \multirow{2}{*}{ Species } & \multicolumn{2}{|c}{ Year 1 } & \multicolumn{2}{c|}{ Year 2 } & \multicolumn{2}{c|}{ Year3 } & \multicolumn{2}{c|}{ Year 4 } \\
\cline { 2 - 9 } & Increments & FiSAT & Increments & FiSAT & Increments & FiSAT & Increments & FiSAT \\
\hline R. decussatus & 17.43 & 19.69 & 22.83 & 23.84 & 26.97 & 26.24 & 30.13 & 29.79 \\
\hline G. pectinatum & 19.50 & 23.79 & 28.50 & 28.82 & 33.00 & 36.20 & & \\
\hline
\end{tabular}
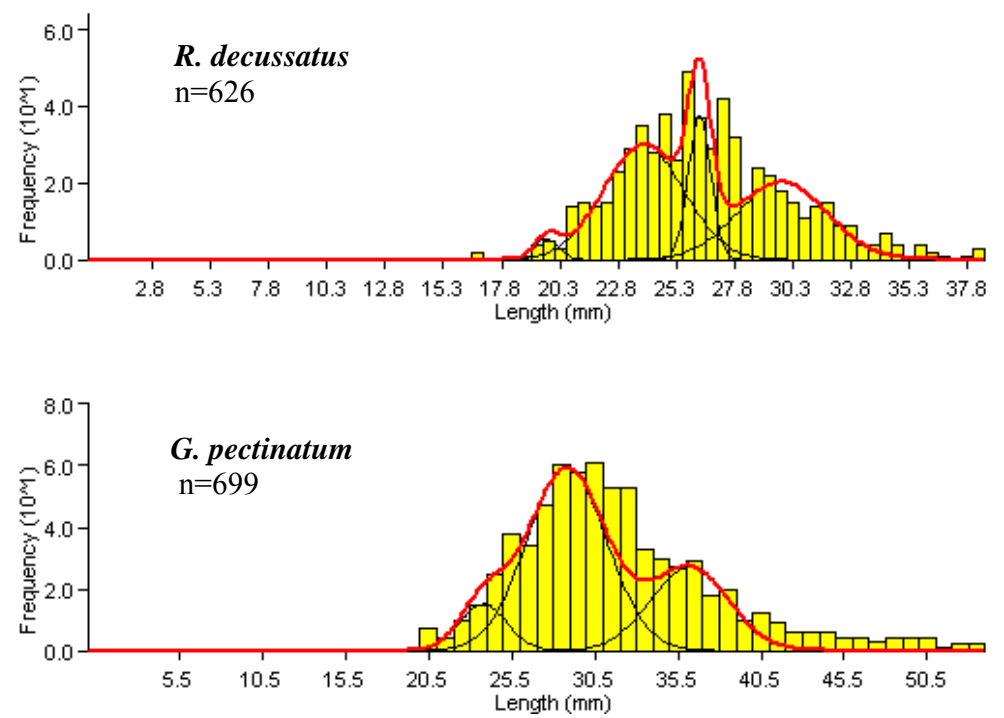

Fig. 4: Composite distribution of the pooled length frequency sample of $R$. decussatus and $G$. pectinatum collected from Lake Timsah determined by Bhattacharya method in FiSAT software. 


\section{Age Validation:}

Percentage of the dark zones in the marginal increment of the shells of $R$. decussatus and G. pectinatum are shown in Fig. 5. The number of the dark zones in the marginal increments of the shells of the two species reached its maximum and minimum in summer and winter, respectively. There was a significant difference in the number of dark zones between different seasons Kruskal-Wallis $P=0.012$ ). Based on these results, the increments analysis shows that a single increment is formed in the two clam species annually starting in summer months in Lake Timsah.

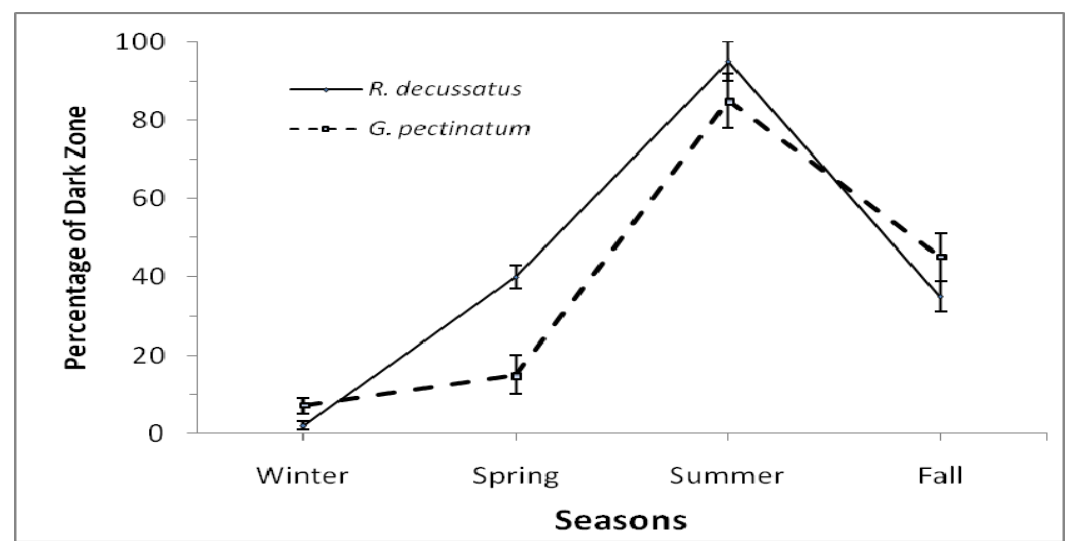

Fig. 5: Seasonal variation in the number of the dark zones associated with the shell margin of $R$. decussatus and G. pectinatum (Error bars $= \pm \mathrm{SE}$ ).

\section{DISCUSSION}

The validation of annual deposition of growth bands is essential to support the use of the number of these bands as age indicator. In the present study, the method of edge analysis was applied in order to confirm this hypothesis and to allow understanding of when they are deposited. The drop in the percentage of dark zones between summer and winter supports the hypothesis of annual band formation of the two species. The method also showed that the period of major growth was summer while slower growth was documented in winter as shown in the change in the frequency of dark zone of the marginal region. This is similar to that observed for the Greenland smoothcockle in Eastern Canada (Kilada, et al., 2007), in which a single annual band is proven to be deposited during summer months. In Lake Timsah, the average water temperature reaches its peak during August and continues to decline till it reaches its minimum in December (El-Shenawy, et al., 2009). Seasonal variation in temperature may be the main reason of the variation in the percentage of dark zone observed on the clam shell. This was documented for other bivalves by Anwar et al. (1990). 
The growth patterns were visible on the external shell surface of the two species where a prominent band separates 2 successive growth increments (Fig. $1)$. The growth in $R$. decussatus is rapid during the first year until it reaches about $17 \mathrm{~mm}$ and slows down thereafter (Table 4). The estimated growth parameters for $R$. decussatus were compared to those estimated in other places (Table 5). In the present study, the asymptotic length $\left(L_{\infty}=40.41 \mathrm{~mm}\right)$ was smaller than that documented in Spain ( $L_{\infty}=45.05 \mathrm{~mm}$, Urrutia et al., 1999). In this study, the authors demonstrated the age-at-length relationship by back calculating the length to each growth band. Maximum age in this study was 6 years as compared to 4 in the present study and this may be the reason of the difference in $L_{\infty}$ values. In contrast, in Greece the asymptotic size was very dissimilar and was larger $\left(L_{\infty}=69.00 \mathrm{~mm}\right.$, Chryssanthakopoulou \& Kaspiris, 2005). Those authors documented that the maximum age was in a $49 \mathrm{~mm}$-clam and was 5 years. These discrepancies could possibly be a consequence of the error in estimating the asymptotic size. When estimating the growth parameter, the authors assumed that the maximum age can reach 19 years, which is not realistic, and also assumed that the clam would be $69 \mathrm{~mm}$ in size. Therefore, the results are age-biased since the life span of $R$. decussatus is less than 6 years.

On the other hand, G. pectinatum showed similar growth pattern. The growth was faster during the first year and then decreased afterwards. The clam was about $20 \mathrm{~mm}, 29 \mathrm{~mm}$ and $33 \mathrm{~mm}$ in the first, second and third years. The length at sexual maturity for G. pectinatum was estimated in the Suez Bay that is located at about $100 \mathrm{~km}$ south of Timsah Lake and was found to be $18 \mathrm{~mm}$ (Gab-Alla et al., 2007). This size corresponds to approximately 1 y in age which means that the species can collected commercially after one year from spawning.

There is no available literatures documenting the growth of this species, nevertheless in India, Jagadis and Rajagopal (2007 a; b) showed that G. tumidum had a different growth rate than $G$. pectinatum (Table 5) which may be explained by the occurrence of different temperature regimes.

Table 5: Von Bertalanffy Growth parameters estimated for different clam species in different locations

\begin{tabular}{|l|c|c|c|l|l|}
\hline Species & $\mathbf{L}_{\infty}$ & $\mathbf{k}$ & $\mathbf{t}_{\mathbf{0}}$ & Location & Reference \\
\hline Ruditapes decussatus & 69.00 & 0.211 & -1.173 & Greece & Chryssanthakopoulou \& Kaspiris, 2005 \\
\hline R. decussatus & 45.05 & 0.026 & 4.052 & Spain & Urrutia et al., 1999 \\
\hline R. decussatus & 40.41 & 0.268 & -1.106 & Egypt & Present Study \\
\hline R. philippinarum & 43.32 & 0.697 & -0.267 & UK & Humphreys et al., 2007 \\
\hline Gafrarium tumidum & 50.67 & 0.288 & -1.05 & India & Jagadis \& Rajagopal, 2007a; b \\
\hline G. pectinatum & 36.31 & 0.81 & 0.053 & Egypt & Present Study \\
\hline
\end{tabular}

The mean length at each age class that was estimated from the lengthfrequency data was similar to the results estimated from age-at-length relationship (Table 4). However, the values obtained from length-frequency 
analysis were slightly larger than those provided from counting the growth increments on the shell surface.

\section{REFERENCES}

Anwar, N. A.; Richardson, C. A. and SEED, R. (1990). Age determination, growth rate and population Structure of the horse mussel Modiolus modiolus. J. Mar. Biol. Ass. U.K. 70:441-457.

Bhattacharya, C. G. (1967). A simple method of resolution of a distribution into Gaussian components. Biom. 23:115-135.

Campana, S. E. (1999). Chemistry and composition of fish otoliths: pathways, mechanisms and applications. Mar. Ecol. Prog. Ser. 188:263-297.

Campana, S. E. (2001). Accuracy, precision and quality control in age determination, including a review of the use and abuse of age validation methods. J. Fish Biol. 59:197-242.

Campana, S. E. and Jones, C. M. (1998). Radiocarbon from nuclear testing applied to age validation of black drum, Pogonias cromis. Fish. Bull. U.S. 96:185-192.

Campana, S. E.; Annand, M. C. and McMillan, J. I. (1995). Graphical and Statistical methods for determining the consistency of age determinations. Trans. Americ. Fish. Soc. 124:131-138.

Carlson, J. K.; Corte's, E. and Johnson, A. G. (1999). Age and growth of the blacknose shark, Carcharhinus acronotus, in the eastern Gulf of Mexico. Copeia 1999:684-691.

Cerrato, R. M. (1980). Demographic analysis of bivalve populations. In: D. C. Rhoads \& R. A. Lutz, editors. Skeletal growth of aquatic organisms Plenum Press. New York. pp. 417-468

Chang, W. Y. B. (1982). A statistical method for evaluating the reproducibility of age determination. Can. J. Fish. Aquat. Sci. 39:1208-1210.

Chryssanthakopoulou, V. and Kaspiris, P. (2005). Age and growth of the carpet shell clam Ruditapes decussatus (Linnaeus 1758) in Araxos lagoon (NW Peloponnisos, Greece). Fres. Environ. Bull. 14:1006-1012. 
El-Shenawy, N. S.; Moawad, T. I. S.; Mohallal, M. E.; Abdel-Nabi, I. M. and Taha, I. A. (2009). Histopathologic biomarker response of clam, Ruditapes decussates, to Organophosphorous Pesticides Reldan and Roundup: A Laboratory Study. Ocean Sci. J. 44:27-34.

Gab-Alla, A. A.; Mohamed, S. Z.; Mahmoud, M. A. M. and Soliman, B. A. (2007). Ecological and Biological Studies on Some Economic Bivalves in Suez Bay, Gulf of Suez, Red Sea, Egypt. J. Fish. Aquat. Sci. 2:178194.

Gabr, H. R. and Gab-Alla, A. A. (2008). Effect of transplantation on heavy metal concentrations in commercial clams of Lake Timsah, Suez Canal, Egypt. Oceanol. 50:83-93.

Gaspar, M. B.; Castro, M. and Monteiro, C. C. (1995). Age and growth rate of the clam, Spisula solida L., from a site off Vilamoura, South Portugal, determined from acetate replicas of shell sections. Scien. Mar. 59:87-93.

Gaspar, M. B.; M.Pereira, A.; Vasconcelos, P. and Monteiro, C. C. (2004). Age and growth of Chamelea gallina from the Algarve coast (southern Portugal): influence of seawater temperature and gametogenic cycle on growth rate. J. Mollusc. Stud. 70:371-377.

Gayanilo, F.C. Jr.; Sparre, P. and Pauly, D. (2005). FISAT II - FAO-ICLARM Stock Assessment Tool, 99 pp. ICLARM, Rome.

Humphreys, J.; Caldow, R. W. G.; Mcgrorty, S.; Westm, A. D. and Jensen, A. C. (2007). Population dynamics of naturalised Manila clams Ruditapes philippinarum in British coastal waters. Mar. Biol. 151:2255-2270.

Jagadis, I. and Rajagopal, S. (2007a). Age and growth of the Venus clam Gafrarium tumidum (Roding, 1798) from Southeast coast of India. Ind. J. Fish. 54:351-356.

Jagadis, I. and Rajagopal, S. (2007b). Reproductive biology of Venus clam Gafrarium tumidum (Roding, 1798) from Southeast coast of India. Aquacult. Res. 38:1117-1122.

Katsanevakis, S. (2007). Growth and mortality rates of the fan mussel Pinna nobilis in Lake Vouliagmeni (Korinthiakos Gulf, Greece): a generalized additive modelling approach. Mar. Biol. 152:1319-1331. 
Keller, N.; Del Piero, D. and Longinelli, A. (2002). Isotopic composition, growth rates and biological behaviour of Chamelea gallina and Callista chione from the Gulf of Trieste (Italy). Mar. Biol. 140:9-15.

Kilada, R.; Campana, S. E. and Roddick, D. (2007a). Validated age, growth and mortality estimates of the ocean quahog (Arctica islandica) in the western Atlantic. ICES J. Mar. Sci. 64:31-38.

Kilada, R.; Roddick, D. and Mombourquette, K. (2007b). Age determination, validation, growth and minimum size of sexual maturity of the greenland smoothcockle (Serripes groenlandicus, bruguiere, 1789) in Eastern Canada. J. Shellfish Res. 26:443-450.

Kilada, R.; Campana, S. E. and Roddick, D. (2009). Growth and sexual maturity of the northern propellerclam (Cyrtodaria siliqua) in Eastern Canada, with bomb radiocarbon age validation. Mar. Biol. 156:1029-1037.

Kimura, D. K. and Lyons, J. J. (1991). Between-reader bias and variability in the age-determination process. Fish. Bull. (Wash. D.C.) 89:53-60.

Labropoulou, M. and Papaconstantinou, C. (2000). Comparison of otolith growth and somatic growth in two macrourid fishes. Fish. Res. 46:177-188.

Laine, A. O.; Momot, W. T. and Ryan, P. A. (1991). Accuracy of using scales and cleithra for aging northern pike from an oligotrophic Ontario lake. N. Am. J. Fish. Manage. 11:220-225.

Morales-Nin, B. and Panfili, J. (2002). Verification. In: J. Panfili, H. de Pontual, H. Troadec, \& P. J. Wright. Manual of fish sclerochronology. Brest, France, Ifremer-IRD coedition. 464 pp.

Peharda, M.; Richardson, C. A.; Mladineo, I.; Sestanovic, S.; Popovic, Z.; Bolotin, J. and Vrgoc, N. (2007). Age, growth and population structure of Modiolus barbatus from the Adriatic. Mar. Biol. 151:629-638.

Quinn, T. P.; Nemeth, R. S. and McIsaac, D. O. (1991). Homing and straying patterns of fall chinook salmon in the Lower Columbia River. Transac. Americ Fish Soc 120:150-156.

Ropes, J. and Jearld, A. Jr. (1987). Age determination of ocean bivalves. In: R. C. Summerfelt \& G. E. Hall, editors. Age and growth of fish, Iowa State University Press, Ames, IA. pp. 517 - 527. 
Serdar, S.; Loek, A.; Koese, A.; Yildiz, H.; Acarli, S. and Goulletquer, P. (2007). Growth and survival rates of carpet shell clam (Tapes decussatus Linnaeus, 1758) using various culture methods in Sufa (Homa) Lagoon, Izmir, Turkey. Aquacult. Eng. 37:89-99.

SYSTAT. (2009). SYSTAT for Windows version 13. SPSS Inc. Chicago, USA.

Urban, H. J. (2000). Culture potential of the pearl oyster (Pinctada imbricata) from the Caribbean. I. Gametogenic activity, growth, mortality and production of a natural population. Aquacult. 189:361-373.

Urrutia, M. B.; Ibarrola, I.; Iglesias, J. I. P. and Navarro, E. (1999). Energetics of growth and reproduction in a high-tidal population of the clam Ruditapes decussatus from Urdaibai Estuary (Basque Country, N. Spain). J. Sea Res. 42:35-48.

Van der Walt, B. A. and Beckley, L. E. (1997). Age and growth of Sarpa salpa (Pisces: Sparidae) off the east coast of South Africa. Fish. Res. 31:241248.

Volk, E. C.; Schroder, S. L. and Grimm, J. J. (1999). Otolith thermal marking. Fish. Res. 43:205-219.

Yassin, M. H.; El-Ganainy, A. A. and Sallam, W. S. (2009). Age, growth and mortality rates of the venerid clam Venerupis aurea in Timsah Lake, Suez Canal, Egypt. Egypt. J. Aquat. Res. 35:317-324 

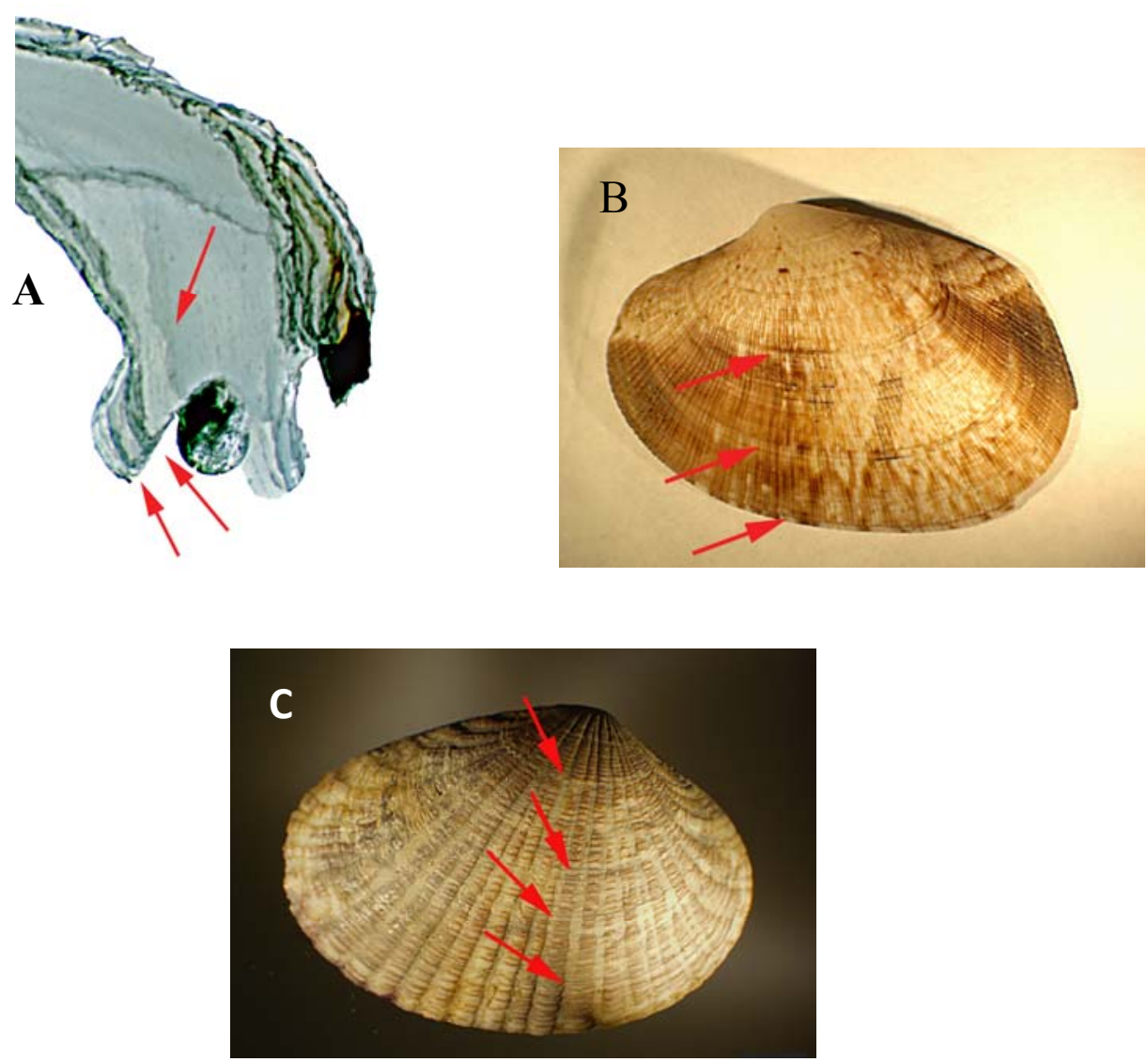

Fig. 1: Growth increments (arrows) visible in various clam species. A. transverse thin section $(140 \mu \mathrm{m})$ of Ruditapes decussatus. B. Shell of Ruditapes decussatus. C. Shell of Gafrarium pectinatum. 